\title{
ARCTIC ENTREPRENEURSHIP DEVELOPMENT FACTORS
}

ABSTRACT. When studying Arctic entrepreneurship, the researcher encounters many paradoxes. Against the background of a powerfully developed topic of entrepreneurship and entrepreneurship in regional science, the layer of work on the entrepreneur in the Arctic is extremely thin. What is even worse - well-known mainstream theories turns out to be unsuitable for the study of Arctic entrepreneurship.

Under these conditions, the only way out for a researcher is to attach to a zonal paradigm and recognize the Arctic as an anti-mainland, and Arctic entrepreneur as the full antipode of a continental fellow. The adherence to the zonal paradigm removes contradictions and equips the researcher with a comparative method to elaborate all facets of the Arctic exceptionalism in the figure of the entrepreneur. The entrepreneur here is understood as a close «relative» to the indigenous peoples and the entire Arctic economy, the Arctic environment, and their specific behavioral traits and adaptation strategies to natural and economic extremes.

The most important factors in the development of entrepreneurship in the Arctic, which create a mosaic picture of situations in the Arctic territories, are: the geographical location - an island or quasi-mainland position; the presence of large resource corporations and a specific stage of their exploitation of the resource field; the institutional structure of the local economy in terms of the degree of nationalization. The cumulative impact of these factors creates a multi-faceted picture, when the Murmansk oblast is at one pole of the extreme favorable conditions for business, and the Chukotka autonomous okrug is at the other extreme hardness.

However, the favorable factors themselves do not guarantee the active development of entrepreneurship. The example of the Murmansk oblast demonstrates the opposite: the conditions for entrepreneurs here are so comfortable that they prefer to slip to the south, where there is no need to bear the burden of northern guarantees and compensations for the employee, and from there to conduct their business activities.

KEY WORDS: Arctic entrepreneurship, factors of development, Arctic economy, marine issues

CITATION: Alexander N. Pilyasov (2020) Arctic Entrepreneurship Development Factors. Geography, Environment, Sustainability, Vol.13, No 1, p. 46-56

DOI-10.24057/2071-9388-2019-91

\section{INTRODUCTION}

In the national project «Small and Medium Entrepreneurship and Support for an Individual Entrepreneurial Initiative», exclusively ambitious tasks are set to reach $32.5 \%$ of GDP and 25 million jobs by the end of 2024 owing to entrepreneurial activity (National project 2019). Given the enormous diversity of the natural and socioeconomic conditions of our country, it is impossible to solve these problems without carefully taking into account local specifics.

The Arctic zone is precisely one of those territories of Russia that are maximally excluded from the general standard of unified federal approaches. And the development of entrepreneurship here is also very specific. So far, the federal policy of support, tuned to the common «arshin»', cannot reverse the negative trends that have developed here in recent years: in 2018 alone, the number of small businesses has decreased by 4,000 and workers by 25,000 people?

When you compare the flow of literature on entrepreneurship within regional science and the flow of literature on Arctic entrepreneurship, bewilderment arises. On one hand, there is a powerful and multi-subject layer of work on entrepreneurship, which for several decades has been developed within the world social science. On the other hand, there is nothing similar inside the Arctic studies: despite the fact that the number of works on Arctic entrepreneurship has been increasing in recent years, very narrow plots are developed, absolutely incomparable in breadth and scope with the work of colleagues in the social science.

Separate articles on individual facets do not capture the general phenomenon of an entrepreneur in the Arctic. But then a natural question arises, on which theoretical platform is a new, holistic view on the problem of entrepreneurship in the Arctic possible? It seems that such a comprehensive view provides a zonal paradigm, that is, a geographical, rather than an anthropological, sociocultural or economic view of an entrepreneur in the Arctic.

Arctic is a special zone of the earth's surface (The Arctic Frontier 1966; UNESCO 2009; Russian Arctic 2014; The New Arctic 2015; Vinokurova et al. 2016; Petrov et al., 2017), so different from the rest, first of all from the temperate zone, densely populated and intellectually dominant in all textbooks, in all theoretical models and constructions, that here it is needed from geography, from natural climatic and socio-economic features to explore the nature, the phenomenon of the Arctic entrepreneur. That is precisely here, in the Arctic zone, geographers can lead specialists from other social disciplines, as nowhere else.

On one hand, low transport accessibility and remoteness of the Arctic regions, small dispersed markets, lack of 
investment, lack of human capital in the Arctic, high costs for heating and electricity, the need to implement northern guarantees and compensations for employees form the strongest barriers to business in the Arctic. On the other hand, the effects of a temporary local monopoly, which small entrepreneurs easily gain here, the unique resources of the Arctic, including its cultural heritage, including indigenous peoples and their traditional knowledge, reindeer herding and traditional hunting, create their comparative advantage against their «fellows» in temperate zone.

Both that radically distinguishes the Arctic businessman from the «mainland». Paradoxical from the point of view of established canons of world social science, Arctic entrepreneurship is much closer to adaptation strategies in the extreme environment of indigenous peoples of the North, with their colossal plasticity and «stretchability» of the size of traditional economy, their ability to constantly maneuver and migrate in a high-risk natural and economic environment, than to the behavior of their fellows in a temperate, densely populated zone of Europe and America.

The purpose of this work is to show the specifics of the Arctic entrepreneurship, to characterize the main factors of its development and to demonstrate its development on the example of a specific Arctic region - the Murmansk oblast.

\section{MATERIALS AND METHODS}

Entrepreneurship in the Russian Arctic is multicolored, from the near-mainland case in large Arctic urban agglomerations to near-rural (as in the rural periphery of central regions of Russia) in the most hard-to-reach areas of the Far North. Therefore, there is a huge temptation to start studying specific cases and not to see the general phenomenon of Arctic entrepreneurship, which is antimainland in its essence, behind the description of individual trees, with all the multitude of local versions and variants.

The only recipe for this danger is to remain loyal to the zonal paradigm (Pilyasov, 2009; Siberian economy through the lenses of the latitudinal zones, 1984). That is, to see above all the general effect of cold discomfort and distance on all other and more particular features of the portrait of an arctic entrepreneur. Not to lose this common is, in our opinion, the real most important task of research on Arctic entrepreneurship. Despite all the local versions, the entrepreneurial class of the Arctic is welded together and is organically close to each other so in the polar cities as on the nomadic sites of private reindeer herders. It is the general pressure of the extreme natural and economic environment that forges this common feature of Arctic entrepreneurs, no matter where they are.

Loyalty to the zonal paradigm immediately reveals the illegitimacy of the concepts, approaches, methodology for describing and studying entrepreneurship for the temperate zone in relation to the Arctic. Take, for example, statistics. It does not distinguish between the entrepreneur of the main settlement zone and the Arctic. Meanwhile, it is obvious that the same data on the development of entrepreneurship in Russia and the Arctic actually means quite different - in one case, the description of a very stationary repetitive phenomenon planted on a statistical reporting «pin»; in another case, suddenly caught up in a digital description of a gust of wind, which tomorrow will be different, and the day after tomorrow - the third. It is like a photograph of a static or impetuous human figure: formally, this is a single phenomenon, but in fact it's about very different states.

The approach to the Arctic as an anti-mainland, which became the basis of our study of Arctic entrepreneurship (see first attempt - Pilyasov, Zamyatina 2016) and which itself, in turn, ideologically flows from the zonal, geographical paradigm, determined the set of analytical tools that was in our hands. First of all, it is a comparative method of research, which was used in a variety of guises.

First, it is a comparison of entrepreneurship in the context of latitudinal zones - the tundra of the Arctic (for example, the Yamalo-Nenets autonomous okrug), the taiga North (Khanty-Mansi autonomous okrug-Yugra), the forest-steppe temperate zone (for example, the south of the Tyumen oblast). The Tyumen oblast in general is the most appreciative object of zonal analysis and comparison in the Russian Federation precisely because here in all three latitudinal zones there is a state regional statistics due to the fact that each of the three regions included in the Tyumen «matryoshka» is a subject of the Russian Federation.

Secondly, it is a comparison of the Arctic and the mainland, the Arctic and Russia, which becomes possible due to the emergence of Arctic statistics in the Russian Arctic as a whole, which Rosstat has been developing since 2017 (Rosstat 2016-2019), including information on individual, small and medium enterprises in the Arctic.

Thirdly, this is a comparison of entrepreneurship within the Arctic itself. Here there are specific difficulties that required the development of a special research position to overcome them.

The fact is that the status of nine regions, fully or partially included in the Russian Arctic, are significantly different. There are four entirely Arctic territories here - this is the Murmansk oblast and three autonomous okrugs - Nenets, Yamalo-Nenets and Chukotka.

There is a separate group of three arctic-northern regions, within which arctic territories fixed by presidential decree and districts of the Far North and / or equivalent to them are separated: Arkhangelsk region without Nenets autonomous okrug, Komi Republic (with Arctic Vorkuta), Karelia Republic with three coastal Arctic regions. There are two vast multi-latitude regions, including the arctic, northern, and even forest-steppe zones - Krasnoyarsk krai, which by its characteristics is often close to the average Russian region, and Republic of Sakha-Yakutia.

Fourthly, this is a comparison of the «quasi-mainland» areas of entrepreneurship within the Arctic itself, which have a permanent ground road connection with central Russia, and «island» areas of entrepreneurship with limited delivery times, which have only seasonal, sea, river, air connection with the «mother» Russia. It can be called a comparison of entrepreneurs «near» and «remote» Arctic. It is clear that in many of their characteristics they will be different: the first closer to the comfortable existence of the mainland entrepreneurs, and the latter - to the type of independent, frontier-type entrepreneurs who perceive their business as a lifestyle.

The main informational basis of the work has been the materials of state statistics on entrepreneurship, which have been considered since 2000s. During this period, the criteria for the small business had been changed several times, separate reporting for the micro-enterprises, for individual enterprises arose, several comprehensive surveys of Russian entrepreneurship had been carried out. But the comparative method allowed us to overcome these turbulences: we selected and fixed stable correlations (Arctic-Russia, ArcticNorth and others), which were maintained during all the transformations. In addition to statistical information, we used materials from our surveys of businessmen in the Arctic during expeditionary surveys of the Nenets, YamaloNenets autonomous okrugs, and the Norilsk industrial region. 


\section{RESULTS}

\section{Arctic entrepreneurship: challenge and response}

In the Arctic, the level of entrepreneurial activity, as measured by the number of small businesses per 10,000 inhabitants, is significantly lower than the average for Russia and the North'. And this ratio, for example, among the three subjects of the Russian Federation of the Tyumen region is steadily reproduced for all the years of observation, despite numerous changes in the criteria who should be attributed to a small entrepreneur: a maximum in the south, average values in the Khanty-Mansiysk autonomous okrug-Yugra, minimum - on the Arctic Yamal.

But at the same time, and this is also confirmed for different years of observation, the average size of a small enterprise (not just a micro, but a small enterprise) in the Arctic is larger than the average for Russia, for example, in Yamal more than in the south of the Tyumen region. And this can be explained by the fact that small business on average in the Arctic is more industrial in nature than on the mainland - plus the fact that traditional non-productive areas of entrepreneurship - trade, personal services - are often sold in the Arctic by state and municipal enterprises. It turns out that the average small business in the Arctic is like a polar bear: there are fewer individuals here in the Arctic than brown bears in the temperate zone, but they are bigger.

The challenge of rising costs from cold and remoteness makes every entrepreneur in the Arctic look for his own creative answer to it. And this search for an answer is the common thing that unites all entrepreneurs of the Arctic zone.

Among all the answers, consider those that are, firstly, recorded by official statistics; secondly, which have a clear arctic specificity. (For this reason, we shall not consider going into illegal status, because, firstly, it is impossible to statistically evaluate this «answer»; secondly, it is difficult to assess the Arctic specificity here without detailed sociological methods).

Given that the small enterprises themselves in the Arctic are comparatively less than on the mainland, the proportion of employed under part-time contracts here is always higher. But you need to look even broader: it's not just parttimers. It is colossal organizational flexibility in all types the combination of budget, corporate employment with entrepreneurship; active attraction of part-timers; strategy of complex specialization in a wide range of goods and services - that helps to neutralize the negative effect of the Northern extra-costs for the Arctic entrepreneur.

Another form of cost reduction is the emphasis to trade mainly of its own products and services - as a rule, to a greater extent than on the mainland and on average in Russia. For example, on average in Russia this share for small enterprises in 2018 was 39,8\%, for the Chukotka autonomous okrug (CHAO) - 72.8, for the Yamalo-Nenets autonomous okrug (YANAO) - 55.4\%, for the Nenets autonomous okrug (NAO) - 52.8\%, for the Murmansk oblast - $50,4 \% 2$. Arctic entrepreneurs have less opportunity to sell other firms products, because this requires better logistic schemes, better road infrastructure than in the Arctic. And here any movement of cargo is expensive and the risks are high.

It is not surprising that the Arctic autonomous okrugs, which are characterized by the most harsh natural and economic conditions, have the maximum share of parttimers and products/services of their own production in the total sales (Table 1).

Another creative response of the Arctic entrepreneur to the challenges of the northern costs is constant mobility. The Arctic business can be fully called a business «on its feet»: it is impossible to be successful here, constantly not moving in the space between the input supply base and numerous local markets.

But after all, a successful entrepreneur on the mainland is also mobile. The difference is that the comparative role and time to travel in the Arctic is higher: the «travel» costs here are simply organically integrated into the business. The phenomenon of mobility seems to be the same, but its role in business success is many times higher in the Arctic than on the «mainland».

In conditions of remoteness, the value of mobility for an entrepreneur goes far beyond the traditional interaction with suppliers and consumers. Both business trips and vacations work for the Arctic entrepreneurship: here, mobility at the same time provides for picking up new knowledge, new technologies and business schemes that come from the mainland and can be used constructively in the Arctic.

For the Arctic entrepreneur, success increasingly depends not only on labor and capital as the key factors of production before, but on their own ingenuity, innovation, which are impossible without extracting new knowledge from outside and relying on talent. And it is precisely mobility that helps

Table 1. Part-timers and the dominance of their own products in the total sales as mechanisms for reducing Arctic costs for entrepreneurs

\begin{tabular}{|c|c|c|c|}
\hline & 2011 & 2014 & 2018 \\
\hline \multicolumn{2}{|c|}{ The share of external part-timers in small enterprises (without micro-enterprises), $\%$} \\
\hline Arctic - YANAO & 20 & 10 & 15 \\
\hline North - KHMAO-YUGRA & 10 & 10 & 9 \\
\hline South of Tyumen oblast & 10 & 10 & 8 \\
\hline \multicolumn{2}{|c|}{ The share of own production in total sales of small enterprises (without micro-enterprises), $\%$} \\
\hline \multicolumn{2}{|c|}{60} & 50 & 55,4 \\
\hline Arctic - YANAO & 60 & 60 & 57,7 \\
\hline
\end{tabular}

Source: collections of «Small and medium-sized enterprises in Russia» for 2011, 2014, 2018: https://www.gks.ru/folder/210/ document/13223

'Rosstat, 2016-2019. Available at:http://Www.gks.ru/free_doc/new_site/region_stat/arc_zona.html Accessed 15 July 2019

${ }^{2}$ http://Www.gks.ru/free_doc/new_site/region_stat/arc_zona.html 
an entrepreneur to be the first to deliver innovation to his community, to the local market, and to get his temporary monopoly on this.

And this is all the more important when there are no universities and research centers nearby, from which knowledge flows to the entrepreneur in developed regions for subsequent commercialization. Here, the search for a novelty is entirely the responsibility of the entrepreneur himself, he does not have either partners or assistants here. Apart from the Internet, which Arctic entrepreneurs use in their business (to find partners, to discover new technology, to search for personnel, etc.) much more active than their colleagues on the mainland (Rosstat 2016-2019)

And this is not surprising: after all, on the mainland, an entrepreneur is always on hand with alternative sources for obtaining important business information, which the Arctic entrepreneur is deprived of.

Our expeditionary surveys of businessmen in the Arctic confirm that there is a combination of Internet and «live» search: partners for Internet negotiations are often determined first, which are then checked during business trips. The Internet in no way reduces the significance of personal communications with business partners, which for an Arctic entrepreneur are associated with significantly more time consuming process than for an entrepreneur on the mainland. In the conditions of Arctic remoteness, paradoxically, the role of such a «temporary proximity» (Rallet, Torre 2009), formed as a result of business trips to the mainland of an Arctic entrepreneur, for picking up new business ideas, for the process of educating an entrepreneur, is simply unprecedented.

The economic landscape of many cities and settlements in the Arctic is formed by the supply bases for storage of goods brought into during the summer navigation. All subjects of the Arctic economy, both large corporations and small businesses, are doomed to create stocks of means of production and consumer goods due to the high cost and irregularity of supplies from the mainland. Working «from the wheels», as is customary for entrepreneurs in central Russia, is simply impossible here.

It is not surprising that the Arctic entrepreneur in the most widespread production activities - in construction and transport, in contrast to the northern and southern ones, has much larger areas of industrial premises. There are no such differences in trade and business services - here the Arctic entrepreneur has less storage space than the northern and southern ones (Table 2).

Previously, under the Soviet planned economy, state schemes for the provision of products to the North and the Arctic had been centralized and unified - from several supply base centers and under one transport scheme (to the Arctic mainly along the Northern Sea Route). Such a typical scheme of delivery clearly demonstrated the homogeneity of the space of the «state» Soviet Arctic.

But now the space of the «new» Arctic is highly differentiated, and therefore there is a triumph of private decisions instead of the former unified delivery of goods, which to the maximum extent take into account the peculiarities of the place, and not the Arctic as a whole. The effect on economy of scale in the case of icebreaking caravan pilotage along the Arctic coast (with entry into all main ports-entry bases) is replaced by the effect on economy on diversity.

Each entrepreneur chooses his own «capillary» (for example, along rivers and winter roads), an economically feasible supply scheme from the continental rear bases and relies on his own base of goods storage at the «entry» point. Creative logistics for an Arctic entrepreneur is the most important way to reduce northern production costs. The strength of an Arctic entrepreneur is precisely to take into account the peculiarities of his place and his markets and, through this consideration of specifics, to fight and conquer northern extra-costs. In this sense, he is doomed to be the genius of a place.

If we try to see the total in the infinitely varied schemes of curbing the high costs of doing business in the Arctic, which are used by local entrepreneurs, then this will be an extremely dynamic, constantly changing combinatorics of production relations and niche markets. The mainland entrepreneur, imitating the large structures in which he wants to grow, is prone to stability and settled position.

On the other hand, the Arctic entrepreneur, quite the opposite, sees his benefits in the constructive exploitation of mobility and instability, to which he is ready every day. In the end, it is they who give him a chance to become a local monopoly and get his margin on it! For most of them it makes no sense to grow in the local small markets, and often this is simply impossible. In Alaska, there is even such a concept of «lifestyle business» (business as a lifestyle) - this is when entrepreneurs are satisfied with the existing size of their company and do not strive for growth (Northern Opportunity 2017).

\section{Arctic entrepreneur as a mirror of the Arctic economy}

Any regional entrepreneurship is always a copy of the structure of the local economy, the settlement system, the characteristics of local communities and their cultural traditions. But for Arctic entrepreneurship because of the vivid

Table 2. The presence of specially equipped premises of small and medium-sized businesses - legal entities by type of economic activity (according to the results of complete observation for 2010)

\begin{tabular}{|c|c|c|c|}
\hline & \multicolumn{3}{|c|}{ Per one enterprise having a specially equipped room } \\
\hline Name & \multicolumn{3}{|c|}{ Total area of premises squ m } \\
\hline Total & YANAO & KHMAO-YUGRA & South of Tyumen oblast \\
\hline Building construction & 593.8 & 563.5 & 737.1 \\
\hline Transport and communication & 1219.5 & 883.6 & 749.6 \\
\hline Real estate transactions, rental and provision of services & 477.8 & 643.9 & 547.3 \\
\hline $\begin{array}{c}\text { Wholesale and retail trade; repair of motor vehicles, } \\
\text { motorcycles, household goods and personal items }\end{array}$ & 306.3 & 401.6 & 555.3 \\
\hline
\end{tabular}

Source: Rosstat, results of a one-time survey of small businesses in 2010 
specifics of the Arctic, this is doubly true. Entrepreneurship here really embodies the special features of the Arctic economy itself, its small size, dependence on life-supporting transport and energy infrastructure, instability, ethnicity, storage / reservation syndrome.

To fully understand the deep nature of Arctic entrepreneurship, it is necessary to see his organic connection with the indigenous peoples of the North living here for centuries and strategies of adapting of their traditional economy to this extreme environment. It is necessary to see in the entrepreneur's daily response to the challenges of the Arctic remoteness and cold discomfort relatedness to the behavior of the Arctic natural systems: technology monitored by the entrepreneur from nature is usually the most economical.

Entrepreneurs of the Arctic fully perceive the natural Arctic rhythm - super-fast deployment in a favorable short summer season, and when adverse conditions occur, the same rapid coagulation as in winter hibernation, to reappear in a new place at a favorable time. Let us call this property as the «mercury»like behaviour of the businessmen of the Arctic. Indeed, the share of ultra-dynamic enterprises in terms of growth or extinction in the Arctic is higher than in the north and in the south (Table 3). The accelerated Arctic rhythm characteristic for natural systems here is also fully manifested in the Arctic entrepreneurship.

Researchers of the indigenous peoples of the North (Krupnik 1989 et al.) note the unparalleled plasticity of the internal structure (flexibility of countless recombinations) of traditional economy (reindeer herding and traditional crafts), which ensures its ability to withstand the incredible amplitudes of natural conditions and ultra-fast changes in the natural environment and climate without breakdowns. But to the same extent, this is also true for an entrepreneur in the Arctic: his legal or illegal enterprise is a really temporary, nonstationary coalition on a type of activity that has temporarily become economically attractive. Changing clothes from an entrepreneur to a public sector worker in the small and fine Arctic labor market is not a big deal on the go. Many do this many times during their working life.

To maintain its viability, this firm enters into very mobile and volatile coalitions (daily changing unions and associations) with other participants - corporate, government and other business structures. This associated character is «catched» by Arctic businessmen from the indigenous peoples.

In the Arctic, there is not enough economic density to create the conditions for competition of small businesses. But if there is no market, market competition, then what then creates the conditions for constructive selection, for selecting the most economically viable entrepreneur?

This selection is here due to the factors of the natural and socio-economic environment, which has the properties of colossal instability and variability. The rapid change of natural and economic conditions, economic configurations, unions, associations with a small number of economic entities themselves form a constructive pressure and cause selection among the participants of the local economy.

On the mainland, competition unfolds in the background of a relatively stationary natural and socio-economic environment. And in this context, it is constructive to select the best entrepreneurs. But in the Arctic, in a colossally unsteady environment, the intensification of the forces of competition is simply destructive. Therefore, there exists a mobile dialectic of local monopolies and non-stationary environment, which, on the one hand, supports the sustainability of business development; on the other hand, it provides a constructive selection pressure on economic actors.

How does this specifically look like? The number of births of new firms (for example, per 1000 residents) is relatively less here than on the mainland. But the dynamics of changes in their states, the transition from one phase to another is more powerful and steeper here than in the developed zone. And this very quick flashing of states, branching of trajectories, such an economic combinatorics of different types creates the conditions for the selection of the optimal state and the optimal solution. The actors themselves do not create diversity here, in which only the forces of selection work. They are too few. But a mobile change of states of the environment creates such conditions of the necessary diversity.

When they say that small business creates a competitive environment and contributes to a constructive selection, it is definitely not about the Arctic. Business here is small and can not create competition. The realities of the business of the Arctic - each monopoly sits in its garden bed and carefully protects it. What then protects against social sclerosis? Colossal variability and instability of the environment of activity of economic entities! Working in a highly unsteady environment and lack of competition are the main differences between the Arctic small business and the mainland.

The conditions of competition of the mainland entrepreneur are pushing him to choose a growth strategy, expansion as the only correct one. Butfor an Arctic entrepreneur working in the conditions of natural and economic extremes, but outside the harsh pressure of competition, growth values are not a priority. It is more important for him to be necessary for his community, to preserve the lifestyle of his ancestors, to ensure the standard of life for his family. Fulfillment of these tasks does not require expansion of the business to new niches and markets. But this principle of reasonable sufficiency is fully inherent in the traditional way of the indigenous people: it is important to be generous among partners, and not to be first among competitors.

Therefore, Arctic entrepreneurship is a very specific kind of human economic activity in the harsh conditions of low transport accessibility, remoteness, small dispersed markets, high costs for heating and electricity, and with specific features of mobility, local monopoly, traditional local knowledge which are all utilized to overcome the challenges of the extreme natural conditions.

Table 3. The proportion of «extreme» enterprises (by dynamics of the number of employees),\%

\begin{tabular}{|c|c|c|c|c|}
\hline & Fast growing & & Fading away & \\
\hline & 2017 & 2018 & 2017 & 2018 \\
\hline YANAO & 1.06 & $0.84(59)$ & 5.09 & 6.07 \\
\hline KHMAO-YUGRA & 0.80 & $0.82(215)$ & 4.98 & 3.95 \\
\hline South of Tyumen oblast & 0.56 & $0.54(207)$ & 4.14 & 3.23 \\
\hline Reference: Russia & 0.72 & 0.58 & 3.89 & 6.35 \\
\hline
\end{tabular}

Source: collections of «Small and medium-sized enterprises in Russia» for 2017, 2018: https://WwW.gks.ru/folder/210/document/13223 


\section{Factors of development of Arctic entrepreneurship}

The results of our expeditionary and sociological surveys of Arctic entrepreneurs in single-industry towns of Yamal autonomous okrug convince us that the differences between Arctic and mainland entrepreneurs even of one type of activity in current economic behavior and business strategies turn out to be even greater than differences between entrepreneurs of different specializations, for example trade and manufacturing business. The most important reason is the zonal, geographical factor, which sharply separates the businessmen of the Arctic from all the others, even irrespective of the particular specialty chosen by him. The commonality of entrepreneurs on the Arctic conditions is stronger than industry differences.

Based on this, let us focus primarily on the specific Arctic factors of entrepreneurship development, which have a powerful effect on the daily life of local business ${ }^{1}$. The first in this series will be the transport distance, that is, the island or «mainland» position of a particular Arctic territory.

It is clear that the Arctic «islands» absolutely transportisolated from mother Russia are like «double Arctic»: the negative effects of northern prices, remoteness from centers of state and municipal support, the benefits of a monopoly position on tiny local markets, the influence of the traditional way of indigenous peoples of the North and Russians oldtimers are manifested here with increased force.

«The development of small and medium-sized businesses in a closed city is not an easy task. The main principle of market competition does not work here - that is, the strongest survives. On the mainland, the competitive struggle gives entrepreneurs the strongest impetus to development. Moreover, partly competition arises because of migrants. In Norilsk, this mechanism does not work because of its remoteness from the mainland» (Present and future of SME in Norilsk 2019).

On the other hand, the presence of a regular ground connection with the main settlement zone turns such areas of the Arctic into a «quasi-mainland». Here the layer of entrepreneurship is already more dense and the effects of competition are beginning to work, centers of state support are closer and it is easier to get it.

The analysis of two official lists - areas of the Arctic and areas with limited time for provision of goods - allows us to highlight three situations: complete coincidence of the lists, when all the Arctic areas are simultaneously transportisolated, and the entrepreneurs here fully embody the «interior» Arctic specificity; partial coincidence when inside the Arctic area one can distinguish districts with limited time for delivery of the «genuine» Arctic in terms of all effects for business activities, and areas that are within the national road network, and therefore the conditions for business activities here bear features of both the Arctic zone and « the mainland «; and the situation when the Arctic regions and the seasonal navigation areas do not coincide at all - the Arctic entrepreneurs of these regions are affected by both Arctic and continental factors (Table 4).

Table 4. Two cases of Arctic entrepreneurship - in the «island» and «quasi-mainland» Arctic

\begin{tabular}{|c|c|c|}
\hline & Arctic districts (Presidential Decree 2019) & Districts of Limited time of Delivery (The list of areas, 2016) \\
\hline \multicolumn{3}{|l|}{ Complete coincidence } \\
\hline $\mathrm{NAO}$ & All districts & All districts \\
\hline $\mathrm{CHAO}$ & All districts & \\
\hline $\begin{array}{l}\text { Republic } \\
\text { of Sakha-Yakutia }\end{array}$ & $\begin{array}{c}\text { Allaikhovskiy, Anabarskiy, Bulunskiy, Nizhnekolymskiy i } \\
\text { Ust'-Yanskiy; Abyyskiy, Verkhnekolymskiy, Verkhoyanskiy, } \\
\text { Zhiganskiy, Momskiy, Olenekskiy, Srednekolymskiy i Eveno- } \\
\text { Bytantayskiy districts }\end{array}$ & $\begin{array}{l}\text { All districts and settlements excluding cities of Aldan, } \\
\text { Tommot, settlements of Leninskii, Nizhnii Kuranakh of } \\
\text { Aldan district and city of Neryungri }\end{array}$ \\
\hline Krasnoyarsk krai & $\begin{array}{l}\text { Territories of the urban district of the city of Norilsk, Taimyr } \\
\text { Dolgan-Nenets Municipal District, Turukhansk District }\end{array}$ & $\begin{array}{l}\text { Boguchansky, Yenisei, Kezhemsky, Motyginsky, North- } \\
\text { Yeniseysky and Turukhansky districts; city of Igarka and } \\
\text { Norilsk, Taimyr Dolgan-Nenets Municipal District }\end{array}$ \\
\hline \multicolumn{3}{|l|}{ Partial coincidence } \\
\hline Murmansk oblast & All districts & $\begin{array}{l}\text { Chavanga, Chapoma, Tetrino and Pyalitsa villages of the } \\
\text { Terek district; Kanevka, Krasnoshchele and Sosnovka } \\
\text { villages of the Lovozero district; Ostrovnoy city, Lumbovka, } \\
\text { Korabelnoye, Svyatoy Nos, Cape-Cherny, Mayak- } \\
\text { Gorodetsky and Terek-Orlovsky Mayak of Ostrovnaya } \\
\text { closed administrative territorial formation }\end{array}$ \\
\hline $\begin{array}{l}\text { Archangelsk oblast } \\
\text { (without NAO) }\end{array}$ & $\begin{array}{c}\text { City of Arkhangelsk, Mezensky District, Novaya Zemlya, } \\
\text { City of Novodvinsk, Onega District, Primorsky District, City } \\
\text { of Severodvinsk }\end{array}$ & $\begin{array}{l}\text { Verkhnetoemsky, Lensky, Leshukonsky, Mezensky, } \\
\text { Pinezhsky, Primorsky and Shenkursky districts }\end{array}$ \\
\hline YANAO & All districts & $\begin{array}{l}\text { all districts and settlements, with the exception of } \\
\text { Labytnangi, Muravlenko, Novy Urengoi and Noyabrsk cities }\end{array}$ \\
\hline \multicolumn{3}{|l|}{ No matches } \\
\hline Republic of Karelia & Belomorsky, Loukhsky and Kemsky districts & $\begin{array}{c}\text { Kalevala National District; Valaam village of Sortavalsky } \\
\text { urban settlement }\end{array}$ \\
\hline Republic of Komi & Vorkuta City District & Other districts \\
\hline
\end{tabular}

'At the same time, of course, we are well aware of the non-geographical factors for the development of entrepreneurship, to which dozens of works of our colleagues are devoted: the general level of education of the population, the presence of a university, the size of local demand, the culture of entrepreneurship, the level of crime and the strength of legislative protection of property rights, the share of migrants in the population etc., but here we shall not concentrate on them. 
The dichotomy of the two Arctics - island and quasimainland in terms of the complex of natural and socioeconomic conditions for entrepreneurship is so informationintensive that it fully captures the features of natural extremity: the Murmansk oblast, the Arkhangelsk oblast and three coastal regions of the Republic of Karelia, in which the Arctic territories are connected by year-round transport network with the «mother» Russia and are more comfortable in natural and climatic conditions. Polar Vorkuta and the major cities of the Yamalo-Nenets autonomous okrug occupy an intermediate position: there is a constantly working railway network, which partially mitigates the effects of natural discomfort factors. On the other hand, the Nenets, Chukotka autonomous districts, the Arctic of Yakutia and the Krasnoyarsk krai are territories of the ultimate embodiment of the Arctic specificity and the strongest operation of all Arctic factors (both negative and positive) in the development of entrepreneurship.

The second factor is the presence or absence of a large resource corporation that mines the hydrocarbon or mineral deposits. Of course, a specific role is also played by the concrete phase of exploitation of the resource object - the stage of «fountains», stabilization or extinction. It determines the real possibilities of the corporate structure to pick up the functions of local life support in the Arctic cities and towns of the company's presence.

The results of our surveys of single-industry cities of Yamal and Ugra, Norilsk, convince us in the duality of the impact of corporate structures of the Arctic on the development of local entrepreneurship. On the one hand, the level of wages in companies is often such that it leads to a total staff shortage in all other areas of activity, including business: energetic and entrepreneurial local talents are massively flowing into the corporate contour from the local budget and business sector. In a number of cases, a personnel «desert» arises next to a large company. In addition, often large companies that become structure-forming for the local economy of remote Arctic villages and cities, take on the functions of maintaining the local life-support systems - trade, personal services, transport, energy, etc., and therefore «take out» these areas of traditional entrepreneurial activity from local businesses.

On the other hand, large companies also create a field of opportunities for small businesses, and, what is important to emphasize, not only in the form of orders and contracts for small business (as follows from the classic courses in business schools), but also due to the fact that the employees in the resource corporations very often create their own «parttime» business, in which they realize their creative plans more fully and boldly than in their corporate company. There are many such examples, for example, in Norilsk, where many employees of the Norilsk Combine are at the same time businessmen in private carriages (taxis) or in the personal services sector.
The third factor in the development of Arctic entrepreneurship is institutional. To what extent are the traditional areas of entrepreneurial activity — trade, services, and others - «closed down» by state or municipal enterprises - in those cases where there are no large corporate structures nearby that could also take up these tasks?

The statistics confirm that while the role of state and municipal structures in general in the Arctic is higher than in Russia, specific variations of the situation are very strong (Table 5). At one extreme is Chukotka autonomous okrug, in which there is no large integrated corporate structure and therefore the state and municipalities are forced to accept many of the tasks of daily life-support for themselves, which is impossible for a business to carry out profitably. But this means that for entrepreneurship there remain narrower spheres of industrial activity, and construction or transport.

At the other extreme is the Murmansk oblast, in which relatively comfortable climatic and socio-economic conditions allow many daily life support functions to be performed by local businesses or business from neighboring regions of the temperate zone. It is not surprising that here the share of enterprises in state and municipal ownership is minimal.

It turns out that inside the «united» Arctic, in fact, the business is in very different conditions: from the Murmansk oblast, which has a permanent land connection with «mainland» Russia, proximity to large urban European centers, relatively comfortable climatic conditions, the presence of large resource corporations in the mining industry and a wide free field for the activities of entrepreneurs, and to the Chukotka autonomous okrug, which is extremely remote from the main settlement zone; has more severe climatic conditions; and very localized activity of resource corporations (due to their rotational scheme of development), the benefits of which are «spilled» only on the nearest national village; as well as a very narrow scope of activity that is attractive for entrepreneurs.

A separate factor in the development of entrepreneurship is state support measures. Sociological surveys of dozens of Yamal entrepreneurs, undertaken in 2016-2017 as part of work under grant 16-46-890363 r_a «Arctic entrepreneurship as a factor of sustainable development of the Yamalo-Nenets autonomous okrug» confirmed the presence of two groups of entrepreneurs: of the frontier type, who consciously refuse any state support, not wanting to lose independence in the management of their business (they are often located in more isolated and remote areas of the Arctic); and entrepreneurs who are very «creative» in adaptation of their activities under the current rules and norms of state and municipal support. According to the analysis of regulatory legal acts of nine Arctic regions and a dozen cities according to Consultant + database, it is possible to isolate unified measures that are indifferent to Arctic specifics, and measures that take into account the peculiarities of the Arctic economy. Let us dwell on the latter.

Table 5. The share of enterprises in state and municipal ownership in the total number of enterprises, 2016, $\%$

\begin{tabular}{|c|c|c|}
\hline Arctic & The share of enterprises in state ownership & The share of enterprises in municipal property \\
\hline CHAO & 20.3 & 20.4 \\
\hline NAO & 19.3 & 8.8 \\
\hline YANAO & 3.9 & 8.2 \\
\hline Murmansk oblast & 4.0 & 6.0 \\
\hline Reference: Russia & 2.3 & 4.3 \\
\hline
\end{tabular}

Source: Rosstat, 2016-2019. Available at: http://www.gks.ru/free_doc/new_site/region_stat/arc_zona.html Accessed 15 July 2019 
Dozens of «Arctic» measures of state and municipal entrepreneurship support programs can be grouped into five areas, which clearly reflect the features of economic activities in the Arctic and confirm our conclusion that entrepreneurs in the Arctic are flesh and blood of the Arctic economy itself.

Firstly, these are subsidies for organizing the northern provision of food and consumer goods to hard-to-reach localities in the form of compensation for a part of transport expenses to entrepreneurs, compensation for a part of expenses on paying interest on bank loans for organizing northern delivery. Within this direction, it is possible to allocate separately subsidies for the delivery of goods (including firewood) to trading posts, in the place of compact residence of the indigenous peoples of the North. Any merchandise movement in the Arctic is associated with increased friction due to very poor transport conditions and it is natural that entrepreneurs who are willing to work in the northern supply market (and this is primarily the European Arctic, because in the Asian part this field of activity is even less attractive for businesses and it is often performed by state, municipal, and corporate structures), and support measures are proposed.

Secondly, these are subsidies (partial reimbursement of transportation costs, etc.) for export, that is, support for the promotion of Arctic products (handicrafts, crafts, reindeer meat) to processing sites and to final markets. The most important limitation in the activity of an Arctic entrepreneur is a small local sales market, which does not allow for the effect of economies of scale on the volume of operations.

«The environment in the city is comfortable for starting a business, the Norilsk residents say. However, when a business crosses a two-year threshold, an entrepreneur does not always understand where to go next». (Present and future of SME in Norilsk 2019).

Even in Norilsk, large by the Arctic standards, local business is quickly sticking to the limits of growth due to limited demand. For many reasons, it is more difficult for an Arctic entrepreneur to move from the internal to the external market than for the mainland. They are more delineated here!

In developed areas, the internal and external markets often overlap, the first organically flows into the second: you have achieved recognition in the local market and become competitive in neighboring markets. But precisely because the «neighboring» markets in the Arctic are far away, to win in the local market, one need completely different qualities and skills than recognition in the outside world.

The domestic market of an Arctic entrepreneur consists of three sectors of the Arctic economy: corporate, state and traditional, on each he provides his services (for example, for the public sector structures or a resource company - services of trade, construction, transport), and inside the traditional one can develop independently in the form of private reindeer herding, for instance. Plus a variety of services to local households. Success requires brilliant implicit knowledge of local specifics, the local community, the local environment and resource potential.

On the other hand, success in neighboring markets requires a completely different knowledge of logistics, tastes of consumers in large cities, competitors' strategies, etc. And the «first» implicit knowledge here doesn't help succeed at all. Therefore, the role of state support for entrepreneurs in the Arctic, to be strengthened in external markets, is comparatively more significant for them than for mainland counterparts.

Transport and energy are two bottlenecks that drive a wave of high costs for an Arctic entrepreneur. Therefore, the third direction is to subsidize the cost of heat and power, including, for example, in greenhouses, marine and fishery bases, the operation of refrigeration units of processing points, as well as ptomoting energy efficiency of entrepreneurs.
Unfortunately, until now the support measures do not encourage replacement of the supply of fuel with their local production (this project is described in detail in Zamyatina, Pilyasov 2019).

The Arctic entrepreneur, unlike his mainland counterpart, is super mobile. That is why the support measures include subsidies for the arrangement of new places of economic activity (the fourth direction) for hunters, for reindeer-herding brigades, for young representatives of small indigenous peoples, who start as entrepreneurs in traditional economic activities.

Finally, the fifth specific Arctic area of business support is grants in the form of subsidies for material and technical equipment and the development of the traditional economic activities of the indigenous minorities of the North. This assistance is aimed at ensuring that from purely subsistence reindeer herding and traditional activities become partially commercial, that is, they would find nearest local markets.

So far, a very small place is occupied by «intellectual subsidies» aimed at acquiring new, including specific Arctic, knowledge by local entrepreneurs: for example, subsidies for conducting geobotanical surveys of reindeer pastures and developing projects for on-farm land management of reindeer pastures; subsidies for energy audits at small businesses; compensation for the payment of training of representatives of small indigenous peoples for the safe handling of weapons, etc.

It is necessary to significantly more actively promote such knowledge spillovers between the Arctic entrepreneurs themselves, between the local and temporary research specialists of the scientific and educational departments and the Arctic entrepreneurs. World experience shows that today, every small business needs periodic «injections» of new knowledge to strengthen its resilience. And this is even more important than the support in the Arctic of creating objects of innovative infrastructure in the form of, for example, business incubators, which in the low-density environment of the Arctic can be the next «cathedrals in the desert».

\section{Murmansk oblast: the contradictions of the expected and the real - how favorable factors close the business opportunities}

For all factors of entrepreneurship development, the Murmansk oblast is the most favorable within the Arctic zone: a simple transport and logistics scheme for the delivery of goods from Central Russia, relatively comfortable environmental conditions for entrepreneurial activities (especially when compared with the regions of the Asian Arctic), comfortable economic conditions due to the many niches and markets, potentially attractive for entrepreneurship; neighbors advanced in terms of entrepreneurship development from the south (Leningrad oblast and St. Petersburg) and from the west (provinces of Norway and communes of Finland).

Therefore, let us consider this polar case (the other - the negative pole according to the conditions of business in the Arctic - is the Chukotka autonomous okrug) in more detail. Here are the largest small enterprises in the Arctic: in other polar regions there are relatively more contract workers, but the size of the company itself is smaller. Here, the largest cumulative turnover of products of individual, small and medium enterprises, however, their number per 1000 people, as a rule, is less than that of their neighbors in the Arctic (Table 6)

By the volume of investments in small business, more than half takes fishery. And this is not surprising - investors in the field of fish processing in coastal municipalities receive state preferences and support. The fish business, due to the very high wages of the employee, significantly raises the 
Table 6. Comparison of the situation in the development of entrepreneurship in the Arctic, Arctic-northern and multilatitude regions of Russia

\begin{tabular}{|c|c|c|c|c|c|}
\hline $\begin{array}{c}\text { Regions in the } \\
\text { Arctic zone }\end{array}$ & $\begin{array}{c}\text { The share of } \\
\text { part-timers in } \\
\text { small enterprises } \\
\text { (without micro), }\end{array}$ & $\begin{array}{c}|c| \\
\text { Increase in the number of small and } \\
\text { medium-sized businesses, \% of the } \\
\text { previous year }\end{array}$ & $\begin{array}{c}\text { Turnover of } \\
\text { products (services) } \\
\text { produced by small } \\
\text { entrepreneurs per } \\
1000 \text { residents - only } \\
\text { the Arctic territories } \\
\text { enterprises, including } \\
\text { micro enterprises } \\
\text { and individual } \\
\text { entrepreneurs, bln } \\
\text { roubles }\end{array}$ \\
\hline Entirely Arctic & 2018 & 2015 & 2016 & 2018 & 2017 \\
\hline Murmansk oblast & 7 & 16.0 & 9.3 & 22.9 & 214.7 \\
\hline YANAO & 15 & -18.5 & 4.2 & 30.6 & 170.7 \\
\hline NAO & 20 & -4.7 & -6.4 & 28.3 & 7.8 \\
\hline CHAO & 15 & 33.2 & -29.0 & 25.4 & 9.0 \\
\hline Arctic-Northern & 12 & -9.7 & -3.0 & 28.2 & 343.1 \\
\hline Archangelsk oblast \\
without NAO
\end{tabular}

Sources: Rosstat, 2016-2019. Available at: http://www.gks.ru/free_doc/new_site/region_stat/arc_zona.htm/ Accessed 15 July 2019; collections of «Small and medium-sized enterprises in Russia» https://WwW.gks.ru/folder/210/document/13223

average earnings of the employee in the entrepreneurial sector throughout the Murmansk oblast.

If we consider the development of business in other sectors, it turns out that the Murmansk oblast, with all its favorable conditions, loses to its Arctic neighbors. Mining small business in the core for the whole oblast economy mineral resource complex practically does not develop, the number of firms here is just scanty and not comparable even with Chukotka autonomous okrug, which is in much more severe conditions.

In the small business of the processing profile, the Murmansk oblast is ahead of the neighboring Arkhangelsk oblast in terms of turnover, although it is inferior in its total number. Due to this segment on the «energy» of import substitution in 2015-2016 in the region there was a general increase in the number of small and medium enterprises. In the rest industrial production small business of the Murmansk oblast is inferior to the Yamalo-Nenets autonomous okrug and the Republic of Karelia.

A natural question arises: what caused the gap in the expected favorable conditions (the best in the Arctic) and the real situation with the development of local entrepreneurship? Indeed, the potential area for the development of entrepreneurship in the Murmansk region is extremely broad, especially in comparison with other Arctic regions, but the entrepreneurial activity itself is very moderate.

It seems that the reasons are enclosed in geography, this time not zonal (that is, physical geography), but economic geography. Paradoxically, it is the favorable factors for the development of entrepreneurship of the Murmansk oblast, that, on the contrary, it inhibits!

The Murmansk region is so comfortable compared to the rest of the Arctic neighbors that many entrepreneurs here prefer not to bear the burden of northern costs and make their lives even more comfortable by relocating their business to the south, to areas where there are no legally enshrined northern guarantees or compensations or where they are essentially more modest than in the Murmansk region. That is why many compensatory effects typical for the entire Arctic zone do not work in the Murmansk region: for example, the active involvement of employees under contracts. Business simply votes with its feet, legally relocated from the oblast to its neighbors to the south, while continuing to work in the markets of the Murmansk region.

Similar effects, only vice versa, were observed during the Soviet era, when new production enterprises were attracted to the southern edge of the North zone as a magnet, because it was easier to find workers from all over the Soviet Union due to attractive northern regional coefficients and seniority allowances. So now the effects of «the opposite» are observed in the entrepreneurship of the Murmansk region, when it is more profitable to legally be deployed to the south in order not to pay northern workers' compensation. And this effect of the economic and geographical situation determines the modern underdevelopment of Murmansk entrepreneurship. 


\section{DISCUSSION AND CONCLUSIONS}

The very study of the topic of the Arctic entrepreneurship highlights the transition of the global Arctic from the managed to entrepreneurial economy. This trend, indicated by researchers another 15-20 years ago (Audretsch D. et al. 2001; Nijkamp P. et al. 2002; Audretsch D. et al. 2004; Baptista R. et al. 2007; Erdos Katalin et al. 2010; Feldman M. et al. 2012), is gradually affecting the Arctic.

Quite recently it seemed that entrepreneurship is not about the Arctic at all and that here this phenomenon is simply impossible due to numerous natural and social barriers. But after all, also in the industrial era, electrification and the conveyor gradually reached the tents of nomadic reindeer herders, although at its start it seemed that this was impossible.

We are on the verge of extensive and comprehensive research on the phenomenon of Arctic entrepreneurship. The need for them stems from at least two reasons: 1) there is an acute shortage of theoretical knowledge on how the development of entrepreneurship in the Arctic submits, to what laws and patterns. The practice here is far ahead of the theoretical understanding of an already phenomenon in play; 2) It is impossible to use research groundwork for the temperate zone here because Arctic entrepreneurship, by its nature, drivers, structure, differs significantly from the «mainland».

For example, what is called ethnic entrepreneurship in Europe and is a small business of recent immigrants, in the Arctic is a business; on the contrary, of the first settlers of this land that is, indigenous small peoples of the North. The textbook presentation is that small business is the most important agent of competition and is always under its own positive pressure. But in the Arctic, on the contrary, small business often uses the effects of a monopoly position, and competition in small and autonomous (dispersed) markets can be simply destructive for the local economy. In the classic works of colleagues from European countries (Audretsch D., Thurik A. 2001 and many others, above mentioned), the stabilizing role of small business is often mentioned. But in the Arctic, on the contrary, entrepreneurship exploits instability in its own interests and is itself the brightest agent of instability, which does not weaken it, but exaggerates it.

One can recognize the phenomenon of Arctic entrepreneurship as «anti-mainland» in nature. But on the platform of the zonal approach, the researcher will not be discouraged by these features and will be able to cope with them and constructively interpret them. This opens up opportunities for the leadership role of geographers in the interdisciplinary research teams studying Arctic entrepreneurs. A proven comparative method of analysis (business of the Arctic and the North, the Arctic and the mainland, etc.) can give here truly constructive results.

«Secret» research method let us understand the nature of the Arctic entrepreneur - to see its essential connection with the indigenous peoples of the North and their strategies to adapt to the extreme Arctic environment, recognize the commonality of the Arctic economy and Arctic entrepreneurship, make sure that taken from nature techniques and technologies are useful and efficient for Arctic entrepreneur.

Nine polar Russian regions can be differentiated into a group of entirely Arctic, Arctic-northern and multi-latitude regions, each of which, along with common features, has its own specific features of local small business development. But common to all of them is the entrepreneur's response to the challenges of northern costs, which consists primarily in unparalleled organizational flexibility, super-mobilty and a brilliant understanding of the place's properties - the local community, the local market, local resources, etc.

The main specific Arctic factors for the development of entrepreneurship, as confirmed by our expeditionary surveys of small businesses in Yamal, are in the geographical location of the main activity sites - island or quasi-mainland, the presence or absence of a large resource corporation and a specific stage of development of the main natural asset (growth, stabilization, decline), institutional structure of the local economy (to what extent are key daily services - trade, transport, household services nationalized) i.e. whether there is a niche for small businesses.

Within the Arctic zone of Russia itself, the situation with regard to the factors of entrepreneurship development is sharply heterogeneous. At one of the most favorable pole is the Murmansk oblast, on the other - the most uncomfortable - the Chukotka autonomous okrug. However, the presence of favorable prerequisites by itself does not guarantee the active development of entrepreneurship. For example, the Murmansk oblast, with all its favorable external factors, is paradoxically not the leader in the development of Arctic entrepreneurship. On the contrary, it is precisely for it that the maximum gap between potential and real state in the development of entrepreneurship is characteristic.

\section{ACKNOWLEDGMENTS}

This article is made possible under the generous support from the RSF grant «Eurasian Vectors of Russia's Maritime Activity: Regional Economic Projections» (project № 19-1800005).

My gratitude to two anonymous reviewers who helped to improve the original version of this article.

\section{REFERENCES}

Audretsch D., Thurik A. (2001). What's new about the new economy? Sources of growth in the managed and entrepreneurial economies. Industrial and Corporate Change, 10(1), 267-315.

Audretsch D., Keilbach M. (2004). Entrepreneurship and regional growth: An evolutionary interpretation. Journal of Evolutionary Economics, 5, 605-616.

Baptista R., Preto M.T. (2007). New Firm Formation and Employment Growth: differences across Regions and Types of Start-ups. ERSA Congress 2007 in Paris.

Erdos Katalin, Varga Attila. (2010). The Academic Entrepreneur: myth or reality for increased regional growth in Europe? ERSA 2010

Congress in Jonkoping.

Feldman M., Zoller T. (2012). Dealmakers in place: Social capital connections in regional entrepreneurial economies. Regional Studies, 1(46), 23-37.

Krupnik I.I. (1989). Arctic ethnoecology. Moscow: Nauka. (In Russian)

National project: Small and medium entrepreneurship (2019). [online] Available at: www.government.ru/info/35563/ [Accessed 15 July, 2019]. (In Russian) 
Nijkamp P., Stough R. (2002). Editorial introduction: Special issue on Entrepreneurship and Regional Economic Development. The Annals of Regional Science, 36, 369-371.

Northern Opportunity. (2017). Alaska's Economic Development Strategy 2017-2022. [online] Available at: www.northernopportunity. com/wp-content/uploads/2017/10/Final-Statewide-CEDS.pdf [Accessed 15 July 2019]

Petrov A.N., BurnSilver S., Chapin S.F., Fondahl G., et al. (2017). Arctic Sustainability Research: Past, Present and Future. Routledge.

Pilyasov A., Zamyatina N. (2016). Arctic entrepreneurship: conditions and opportunities for development. Arctic: environment, economy, energy, 4, 4-15. (In Russian).

Pilyasov A. (2009). Zonal factors of post-industrial transformation (the case of the Russian North). Arctic idea. April. 40-41. (In Russian).

Rallet Alain, Torre André. (2009). Temporary Geographical Proximity for Business and Work Coordination: When, How and Where? [online] Available at: www.researchgate.net/publication/253129792_Temporary_Geographical_Proximity_for_Business_and_Work_Coordination_ When_How_and_Where [Accessed 15 July 2019].

Present and future ofSME in Norilsk (2019). [online] Available at: www.ttelegraf.ru/news/title/v--norilske-predstavili-itogi-kompleksnogoissledovaniya-malogo-i-srednego-biznesa- [Accessed 15 July 2019] (In Russian).

Presidential Decree of May 13, 2019, 220 «On Amendments to the Decree of the President of the Russian Federation of May 2, $2014 \mathrm{~N}$ 296» On Land Territories of the Arctic Zone of the Russian Federation» (In Russian).

Rosstat, statistics on the Arctic zone, 2016-2019. [online] Available at: www.gks.ru/free_doc/new_site/region_stat/arc_zona.html [Accessed 15 July 2019].

Russian Arctic: contemporary paradigm of development. (2014). Ed. by A. Tatarkin. Saint Peterburg. Nestor-istoriya. (In Russian).

Siberian economy through the lenses of the latitudinal zones. (1984). Ed. A. Granberg. Novosibirsk. Nauka. (In Russian).

Small and medium-sized enterprises in Russia. Statistic bulletin. 2010-2018. [online] Available at:www.gks.ru/folder/210/document/13223 The Arctic Frontier. (1966). Ed. by R. St. Macdonald. University of Toronto Press.

The list of areas of the Far North and equated localities with limited terms of delivery of goods (products) (approved by the Government of the Russian Federation on May 23, 2000, 402). With changes and additions from: 27.09.2001, 31.03.2009, 6.12.2016. (In Russian).

The New Arctic. (2015). Eds. Evengard B., Larsen J.N., Paasche O. Springer.

UNESCO. (2009). Climate change and Arctic Sustainable Development: scientific, social and educational challenges. UNESCO: Paris.

Vinokurova U., Yakovets Yu. (2016). Arctic circumpolar civilization. Novosibirsk: Nauka. (In Russian).

Zamyatina N., Pilyasov A. (2019). How do we «equip» the Arctic. Moscow. ANO IRC. (In Russian). 